\title{
PENGARUH PEMAHAMAN WAJIB PAJAK DAN MANFAAT PAJAK RESTORAN TERHADAP KESADARAN WAJIB PAJAK MEMBAYAR PAJAK (Studi Kasus Pada Usaha Restoran Di Kota Tomohon)
}

\author{
Arian Sumando Butarbutar \\ Harijanto Sabijono \\ Heince R.N Wokas
}

\author{
Fakultas Ekonomi dan Bisnis Jurusan Akuntansi \\ Universitas Sam Ratulangi Manado \\ email: ryankandox@yahoo.com
}

\begin{abstract}
ABSTRAK
Penelitian ini bertujuan untuk mengetahui pengaruh pemahaman wajib pajak, dan manfaat pajak restoran terhadap kesadaran wajib pajak membayar pajak. Sumber data yang digunakan dalam penelitian ini adalah data primer yang berasal dari wajib pajak restoran di Kota Tomohon. Metode analisis yang digunakan adalah analisis regresi berganda. Hasil analisis regresi menghasilkan persamaan $r \mathrm{Y}=8.000+0,136 \mathrm{X}_{1}+0,440 \mathrm{X}_{2} \quad$ Nilai $\mathrm{R}^{2}$ sebesar 0,303 menunjukan proporsi kontribusi pemahaman wajib pajak dan manfaat pajak restoran terhadap kesadaran wajib pajak membayar pajak restoran di kota Tomohon sebesar 30.3\%. Dan nilai koefisien korelsi (r) sebesar 0,550. Uji hipotesis dengan menggunakan uji t menunjukan bahwa pemahaman wajib pajak tidak berpengaruh secara parsial terhadap kesadaran wajib pajak membayar pajak restoran di kota Tomohon sedangkan manfaat pajak restoran berpengaruh signifikan terhadap kesadaran wajib pajak restoran di kota Tomohon.
\end{abstract}

Kata kunci: pemahaman wajib pajak, manfaat pajak restoran dan kesadaran membayar pajak

\begin{abstract}
This study aims to determine the effect of taxpayer understanding and awareness of tax benefits to the restaurants taxpayer pays taxes. Sources of data used in this study is primary data derived from taxpayer restaurant in Tomohon. The analytical method used is multiple regression analysis. The results of the regression analysis resulted in the equation $r Y=8.000+0.136 X 1+0.440 X 2 . R 2$ value of 0.303 indicates the proportion of the taxpayer contributes understanding and awareness of tax benefits to the restaurants taxpayer pays tax at a restaurant in Tomohon $30.3 \%$. And korelsi coefficient ( $r$ ) of 0.550 . Hypothesis testing using $t$-test showed that no taxpayer understanding partial effect on consciousness taxpayer pays tax while the restaurant in Tomohon city restaurant tax benefits significantly influence the consciousness of the top tax payers in the city of Tomohon.
\end{abstract}

Keywords: understanding taxpayers, tax benefits awareness restaurants and paying taxes 


\section{PENDAHULUAN}

\section{Latar Belakang Masalah}

Kesadaran dalam membayar pajak dari para wajib pajak bukan hanya sekedar sebagai wacana, tetapi lebih dari itu, kita seharusnya juga memandang kesadaran dalam membayar pajak sebagai objek sorotan secara objektif bahkan mendekati kebenaran dalam mensukseskan program yang dicanangkan oleh pemerintah karna selama ini perekonomian dalam Negeri kita secara umum masi buruk. Harus kita akui juga bahwa ada beberapa sektor usaha (terutama sektor swasta) masih menunjukan kinerja yang cukup bagus, sebagai salah satu contoh adalah usaha restoran yang mulai meramaikan industri jasa maupun indrustri perdagangan. Suatu hal yang paling menentukan dalam keberhasilan pemungutan pajak adalah kemauan wajib pajak terhadap kesadaran membayar pajak.

Kurangnya kesadaran wajib pajak dalam membayar pajak di kota Tomohon karena kurangnya pengetahuan dan tidak menyadari akan manfaat yang dirasakan dari pajak itu sendiri. Wajib pajak akan memahami perpajakan dan akan timbul sikap optimis jika mereka memiliki pengetahuan dan menyadari akan manfaat yang dirasakan dari perpajakan.

\section{Rumusan Masalah Penelitian}

Berdasarkan latar belakang masalah penelitian diatas, maka dapat dirumuskan masalah :

1. Apakah pemahaman wajib pajak tentang peraturan perpajakan berpengaruh terhadap kesadaran membayar pajak restoran?

2. Apakah manfaat yang dirasakan wajib pajak berpengaruh terhadap kesadaran membayar pajak restoran

\section{Tujuan Penelitian}

Tujuan yang hendak di capai dalam penelitian dan penulisan skripsi ini untuk mengetahui pengaruh pemahaman wajib pajak tentang peraturan perpajakan, dan manfaat yang di rasakan wajib pajak terhadap kesadaran membayar pajak restoran.

\section{Manfaat Penelitian}

1. Bagi Peneliti, untuk memenuhi salah satu syarat untuk menyelesaikan program strata satu (S1) pada fakultas ekonomi Universitas Sam Ratulangi dan untuk menerapkan ilmu yang diperoleh di bangku kuliah dan mempraktekkannya sesuai dengan kondisi yang ada.

2. Bagi pemerintah, untuk menjadikan sebagai bahan informasi pelengkap dan masukan sekaligus pertimbangan bagi pihak-pihak yang berwenang yang berhubungan dengan penelitian ini dalam penelitian dua faktor yang mempengaruhi wajib pajak restoran terhadap kesadaran membayar pajak.

3. Bagi pembaca, dengan adanya penelitian ini dapat meningkatkan kesadaran wajib pajak, dan dapat menjadi referensi dalam memahami akan dua faktor yang mempengaruhi wajib pajak restoran terhadap kesadaran membayar pajak.

\section{Konsep Akuntansi Pajak}

\section{TINJAUAN PUSTAKA}

American Accounting Association dalam Soemarso (2005: 3), mendefinisikan akuntansi sebagai proses mengidentifikasikan, mengukur, dan melaporkan informasi ekonomi untuk memungkinkan adanya penilaian dan keputusan yang jelas dan tegas bagi mereka yang menggunakan informasi kegiatan akuntansi dan kegunaan akuntansi.

Horngren dalam Mardiasmo, (2011:4), akuntansi adalah sistem informasi yang mengukur aktivitas bisnis, memproses data menjadi laporan, dan mengkomunikasikan hasilnya kepada para pengambil keputusan.

Trisnawati (2007:5), akuntansi pajak adalah akuntansi yang diterapkan sesuai dengan peraturan perpajakan. Akuntansi pajak merupakan bagian dari akuntansi komersial.

\section{Konsep Pajak}

\section{Definisi dan Unsur Pajak}

Pengertian yang ditulis dalam Muljono (2010), pajak merupakan suatu pengalihan sumber-sumber yang wajib di lakukan dari sektor swasta kepada sektor pemerintah berdasarkan peraturan tanpa suatu imbalan kembali dan langsung dan seimbang. 
Menurut Brotodihardjo (2011:1), pengertian pajak adalah bantuan, baik secara langsung maupun tidak langsung yang di paksakan oleh kekuasaan publik dari penduduk atau dari barang, untuk menutupi belanja pemerintah, yang artinya pajak merupakan suatu pemungutan dari masyarakat yang berguna untuk kepentingan negara.

\section{Fungsi Pajak}

Fungsi pajak yang ditulis dalam Soemitro (2010:1), fungsi pajak terdiri atas beberapa fungsi, yaitu: fungsi anggaran (budgetir), fungsi mengatur (regulerend), fungsi stabilitas, dan fungsi redistribusi pendapatan.

\section{Syarat Pemungutan Pajak}

Syarat-syarat pemungutan pajak menurut Sumarsan, (2012:7) adalah Pemungutan pajak harus adil, Pungutan pajak tidak menggangu perekonomian, Pemungutan pajak harus efisien dan Sistem pemungutan pajak harus sederhana.

\section{Pengelompokan Pajak}

Mardiasmo (2011:5), pajak dapat dikelompokkan sebagai berikut:

1. Menurut golongannya yaitu pajak langsung dan pajak tidak langsung.

2. Menurut sifatnya yaitu pajak subjektif dan pajak objektif.

3. Menurut lembaga pemungutannya yaitu pajak pusat dan pajak daerah.

\section{Tata Cara Pemungutan Pajak}

1. Stelsel Pajak menurut Sumarsan, $(2012 ; 13)$, cara pemungutan pajak dilakukan berdasarkan 3 stelsel yaitu Stelsel Nyata, Stelsel Anggapan, dan Stelsel Campuran.

2. Sistem pemungutan pajak dapat dibagi menjadi: Official Assesment System, Selft Assesment System, dan Withholding System.

3. Asas pemungutan pajak menurut Mardiasmo (2011:7), mengemukakan bahwa asas pemungutan pajak terbagi menjadi tiga, yaitu: Asas Domisili (Asas Tempat Tinggal), Asas Sumber, dan Asas Kebangsaan.

\section{Kewajiban Perpajakan}

Perwujudan dari pengabdian dan sarana peran serta wajib pajak untuk secara langsung dan bersama-sama melaksanakan perpajakan yang diperlukan untuk pembiayaan negara dan pembangunan nasional dengan tanggung jawab atas kewajiban pelaksanaannya dipercayakan sepenuhnya kepada anggota masyarakat.

\section{Konsep Pajak Restoran}

Sesuai dengan Undang-undang Nomor 16 Tahun 2005, pajak restoran adalah pajak atas pelayanan yang disediakan oleh restoran dan yang di maksud dengan restoran adalah fasilitas penyediaan makanan dan minuman yang di pungut bayaran, yang mencangkup juga rumah makan, kafetaria, bar, warung, kantin, dan sejenis lainnya termasuk jasa boga/katering.

\section{Dasar Hukum Pemungutan Pajak Restoran}

Dasar hukum pemungutan pajak restoran pada suatu kabupaten atau kota adalah sebagai berikut:

1. Peraturan pemerintah Nomor 65 Tahun 2001 tentang pajak daerah.

2. Undang-undang Nomor 34 Tahun 2000 yang yang merupakan perubahan atas Undang -undang Nomor 18 Tahun 1997 tentang pajak daerah dan retribusi daerah.

3. Keputusan Bupati/Walikota yang mengatur tentang pajak restoran sebagai aturan pelaksanaan peraturan daerah tentang pajak restoran pada kabupaten/kota yang dimaksud.

4. Peraturan daerah kabupaten/kota yang mengatur tentang pajak restoran.

\section{Objek Pajak Restoran}

1. Objek pajak restoran adalah pelayanan yang disediakan oleh restoran.

2. Bukan objek pajak restoran dalam Undang-Undang Nomor 28 Tahun 2009 Pasal 37 ayat 3 adalah pelayanan yang disediakan oleh restoran yang nilai jualnya tidak melebihi batas tertentu yang ditetapkan dengan peraturan daerah. 


\section{Subjek Pajak dan Wajib Pajak Restoran}

Pada pajak restoran yang menjadi subjek pajak adalah orang pribadi atau badan yang membeli makanan dan minuman dari restoran. Sementara itu yang menjadi wajib pajak adalah pengusaha restoran yaitu orang pribadi atau badan dalam bentuk apapun yang dalam lingkungan perusahaan atau pekerjaanya melakukan usaha dibidang rumah makan.

\section{Dasar Pengenaan Pajak Restoran}

Dasar pengenaan pajak restoran adalah jumlah pembayaran yang dilakukan kepada restoran. Pembayaran adalah jumlah uang yang harus dibayarkan oleh subjek pajak kepada wajib pajak untuk harga jual baik jumlah uang yang dibayarkan maupun penggantian yang seharusnya diminta wajib pajak sebagai penukaran atas pembelian makanan atau minuman.

\section{Tarif Pajak Restoran}

Tarif pajak restoran ditetapkan paling tinggi sebesar $10 \%$ dan ditetapkan dengan peraturan daerah kabupaten/kota yang bersangkutan.

\section{Faktor - Faktor Yang Melatarbelakangi}

Faktor adalah hal (keadaan atau peristiwa) dan sebagainya yang mempengruhi terjadinya sesuatu berdasarkan pengertiannya, keadaan atau peristiwa yang dapat melatarbelakangi terhadap kesadaran wajib pajak restoran dalam membayar pajak adalah Pemahaman Wajib Pajak tentang Peraturan Perpajakan dan Manfaat Yang Dirasakan Wajib Pajak.

\section{Kesadaran Wajib Pajak}

Kesadaran adalah tahu, mengerti, dan ingat kepada hal yang benar. Maka kesadaran wajib pajak terhadap kepatuhan wajib pajak restoran adalah bagaimana wajib pajak menyadari akan membayar pajak.

\section{Pajak Daerah}

Pajak daerah adalah iuran wajib yang dilakukan oleh daerah kepada orang pribadi atau badan tanpa imbalan langsung yang seimbang, yang dapat dipaksakan berdasarkan peraturan perundang-undangan yang berlaku, yang digunakan untuk membiayai penyelenggaraan pemerintah daerah dan pembangunan daerah.

Pajak daerah terdapat dalam undang-undang Nomor 32 tahun 2004 tentang pemerintahan daerah dan undang-undang Nomor 33 tahun 2004 tentang perimbangan keuangan antara pemerintah pusat dan daerah menetapkan bahwa penerimaan daerah dalam pelaksanaan desentralisasi terdiri atas pendapatan daerah dan pembiayaan pendapatan daerah.

\section{Pajak Kabupaten/Kota Lainnya}

Undang-undang Nomor 4 Tahun 2000 memberikan peluang kepada daerah kabupaten/kota untuk memungut jenis pajak daerah lain yang dipandang memenuhi syarat, selain 7 jenis pajak kabupaten/kota yang telah ditetapkan. Penetapan jenis pajak lainnya harus benar-benar bersifat spesifik dan potensial di daerah.

\section{Penelitian Terdahulu}

Dalam melakukan penelitian ini, peneliti melakukan penelitian berdasarkan penelitian terdahulu yang dilakukan oleh Dwi (2010) dengan judul "Analisis faktor-faktor yang mempengaruhi pemilik usaha kecil menengah dalam pelaporan kewajiban perpajakan di Daerah Yogyakarta. (studi kasus pada usaha coffeshop di Daerah Jogjakarta)". Bila dibandingkan dengan penelitian yang akan dilakukan penulis, terdapat persamaan dengan penelitian ini adalah persamaan variabel tetapi dalam penelitian ini penulis hanya mengambil 2 variabel untuk diteliti yaitu pemahaman wajib pajak tentang peraturan perpajakan dan manfaat pajak yang dirasakan wajib pajak terhadap pajak. Sedangkan perbedaannya yaitu hasil penelitian, lokasi dan objek penelitian, dimana Dwi mengadakan penelitian di Daerah Yogyakarta, sedangkan penulis mengadakan penelitian di Kota Tomohon dan objek penelitiannya pada usaha restoran.

William (2006), dengan judul "Pengaruh Pemahaman Wajib Pajak, Persepsi Wajib Pajak tentang Sanksi, dan Pelayanan Pemerintah terhadap Kepatuhan Wajib Pajak (Studi empiris terhadap wajib pajak restoran di Kota Surabaya Cabang Selatan)". Dalam penelitian ini terdapat persamaan dari variable pajaknya dan metode analisis yang di gunakannya, analisis regresi linear berganda. Sedangkan perbedaannya penulis hanya mengambil 2 variabel sedangkan William mengambil 3 variabel, dan lokasi penelitian, dimana Wiliam mengadakan penelitian di Kota Surabaya Cabang Selatan, sedangkan penulis di Kota Tomohon. 


\section{Jenis Penelitian}

\section{METODE PENELITIAN}

Penelitian ini merupakan penelitian asosiatif. Penelitian asosiatif merupakan penelitian yang bertujuan untuk mengetahui pengaruh dua variabel atau lebih.

\section{Tempat dan Waktu Penelitian}

Penelitian ini dilakukan di Kota Tomohon dengan objek penelitian Pengusaha Restoran di Kota Tomohon. Tempat Penelitian adalah Kantor Pelayanan Penyuluhan dan Konsultan Perpajakan (KP2KP) Tomohon yang bertempat di Jl Raya Manado - Tomohon, Kakaskasen III. Periode waktu penelitian dimulai dari akhir bulan Oktober sampai dengan bulan Desember 2013.

\section{Prosedur Penelitian}

Penulis melakukan kajian awal dengan melakukan studi literatur baik studi kepustakaan maupun membaca melalui internet. Kemudian melakukan pengidentifikasian tentang masalah, merumuskannya, menetapkan tujuan atau manfaat penelitian, kemudian membatasi masalah ke lingkup yang disesuaikan dengan penelitian saat ini. Perancangan dan persiapan survai pada objek penelitian yang telah ditentukan, kemudian pengumpulan data baik primer melalui kuisioner kepada wajib pajak badan/pengusaha di kota Tomohon yang terdaftar di KP2KP Tomohon maupun data sekunder. Melakukan pengolahan data, membahasnya kemudian menarik kesimpulan dan memberikan saran-saran guna melengkapi penelitian.

Langkah-langkah yang telah dilakukan dalam penelitian ini adalah sebagai berikut :

1. Perancangan dan Persiapan Survai

2. Pengumpulan Data Primer dan Sekunder

3. Pengolahan Data

4. Hasil dan Pembahasan

5. Kesimpulan dan Saran

\section{Jenis Data dan Sumber Data}

Data adalah keterangan-keterangan mengenai sesuatu yang diperoleh dalam satu penelitian untuk menjelaskan, menerangkan, dan memecahkan masalah-masalah sesuai dengan konteks judul yang diambil dengan maksud tujuan tersebut.

Jenis data menurut Kuncoro (2011), terbagi atas 2 bagian yaitu :

1. Data kualitatif, adalah data yang tidak dapat diukur dalam skala numerik.

2. Data Kuantitatif, adalah data yang diukur dalam suatu skala numerik (angka).

Sumber data Menurut Kuncoro (2011), terbagi atas 2 bagian yaitu :

1. Data Primer adalah data yang di peroleh dengan survei lapangan yang menggunakan semua metode pengumpulan data original.

2. Data Sekunder adalah data yang dikumpulkan oleh lembaga pengumpul data yang di publikasikan kepada masyarakat pengguna data.

\section{Metode Pengumpulan Data}

Teknik pengumpulan data yang digunakan adalah Mengumpulkan informasi yang berhubungan dengan judul, Memperoleh gambaran umum dari objek penelitian, Mengolah data yang diperoleh, Menarik kesimpulan dan memberikan saran.

\section{Populasi dan Sampel}

Populasi adalah kelompok elemen yang lengkap, yang biasanya berupa orang, objek, transaksi, atau kejadian dimana kita tertarik untuk mempelajarinya atau menjadi objek penelitian. Populasi dari penelitian ini adalah wajib pajak restoran yang terdaftar di Dinas Kebudayaan dan Pariwisata Kota Tomohon yang masih aktif menjalankan usahanya sampai pada akhir tahun 2012. Wajib pajak restoran yang terdaftar di Kota Tomohon yang aktif sampai dengan akhir tahun 2012 mencapai 98 restoran, dan yang menjadi sampel adalah sebagai yang mewakili populasi yaitu 50 responden. 


\section{Metode Analisis Data \\ Uji Validitas dan Realibilitas}

Validitas kriteria diukur dengan cara menghitung korelasi antara skor masing-masing butir dengan skor total mengunakan teknik korelasi pearson. Bilamana koefisien korelasi politif dan $\geq 0,3$ maka indikator yang bersangkutan dianggap valid. Kriteria pengujian validiitas yang digunakan atau batas-batas minimum suatu instrument/angket bahan tes untuk dinyatakan valid atau dianggap memenuhi syarat (Solimun 2008). Salah satu pengukuran reliabilitas adalah menggunakan koefisien cronbach alpha, di mana jika nilai Alpha > 0,6 menunjukan instrument tersebut reliabel (Solimun 2008).

\section{Uji Asumsi Klasik}

Asumsi klasik yang digunakan adalah asumsi klasik heteroskedastisitas, multikolinearitas dan auto korelasi. Dalam literature ekonometrika dikemukakan berapa asumsi klasik yang harus dipenuhi oleh suatu model regresi agar model regresi tersebut dapat dipakai.asumsi klasik tersebut adalah bebas heteroskedastisitas, tidak ada multikolinearitas dan bebas autokorelasi.

1. Asumsi Klasik Normalitas

2. Asumsi Klasik Multikolinearitas

3. Asumsi Klasik Autokorelasi

\section{Analisis Regresi Linear berganda}

Analisis regresi linear berganda digunakan untuk meramalkan bagaimana keadaan (naik turunnya) variabel dependen bila dua atau lebih variabel independen sebagai faktor predictor dimanipulasi (dinaik-turunkan nilainya). Pengujian hipotesis-hipotesis dalam penelitian ini menggunakan alat analisis regresi linear berganda. Model analisis regresi linear berganda yang digunakan untuk menguji hipotesis adalah $\quad Y=a+\beta_{1} X_{1}+\beta_{2} X_{2}+\varepsilon$

\section{Pengujian Hipotesis} berikut :

Selanjutnya untuk menguji hipotesis yang diajukan, maka digunakan statistik uji $\mathrm{F}$ dan uji $\mathrm{t}$ sebagai

1. Uji simultan (Uji F) dilakukan untuk mengetahui hubungan variabel independen secara bersama-sama (simultan) terhadap variabel dependen.

2. Uji parsial (Uji t) dilakukan untuk mengetahui hubungan variabel independen secara individual (parsial) terhadap variabel dependen.

\section{Definisi Operasional dan Pengukuran Variabel}

Untuk memberikan pemahaman yang lebih spesifik terhadap variabel penelitian ini maka variabel variabel tersebut didefinisikan secara operasional yaitu kesadaran wajib pajak restoran (Y), pemahaman wajib pajak restoran tentang peraturan perpajakan $\left(\mathrm{X}_{1}\right)$, dan manfaat yang dirasakan wajib pajak restoran $\left(\mathrm{X}_{2}\right)$.

\section{Sejarah Kota Tomohon}

\section{HASIL PENELITIAN DAN PEMBAHASAN}

Tomohon sejak dahulu telah dituliskan dalam beberapa catatan sejarah. Salah satunya terdapat dalam karya etnografis Pendeta N. Graafland yang ketika pada tanggal 14 Januari 1864 di atas kapal Queen Elisabeth, ia menuliskan tentang suatu negeri yang bernama Tomohon yang dikunjunginya pada sekitar tahun 1850 . Menurut beberapa sumber, Tomohon asal kata (Tou mu'ung) dalam bahasa tombulu. Dikatakan bahwa Tomohon adalah salah satu daerah yang termasuk dalam etnis tombulu, ialah salah satu dari delapan etnis asli minahasa. Perkembangan peradaban dan dinamika penyelenggaraan pembangunan dan kemasyarakatan dari tahun ke tahun menjadikan Tomohon sebagai salah satu ibukota kecamatan di Kabupaten Minahasa.

Kota Tomohon diresmikan oleh Menteri Dalam Negeri Hari Sabarno atas nama Presiden Republik Indonesia pada tanggal 4 Agustus 2003 dan saat ini Kota Tomohon terbagi menjadi 5 kecamatan, yaitu:
1. Tomohon Utara
2. Tomohon Tengah
3. Tomohon Timur
4. Tomohon Barat
5. Tomohon Selatan 


\section{Gambaran Umum Responden}

Populasi dalam penelitian ini adalah wajib pajak restoran yang terdaftar di di Dinas Kebudayaan dan Pariwisata Kota Tomohon yang masih aktif menjalankan usahanya sampai pada akhir tahun 2012. Adapun jumlah responden yang di tentukan sebagai sampel adalah sebanyak 50 responden, dengan teknik pengambilan sampel memilih anggota populasi yang paling mudah diakses untuk memperoleh informasi.

\section{Uji Validitas dan Reliabilitas}

Perhitungan uji validitas instrumen menggunakan analisis korelasi pearson dengan bantuan komputer program SPSS. Keputusan mengenai butir item yang dinyatakan valid dengan nilai $r$ hitung dengan nilai $r$ hitung $>0.3$ maka butir item dinyatakan valid. Pengujian validitas dilakukan dengan cara mengkorelasikan antara skor masing-masing butir pertanyaan dengan skor total yang diperoleh dari penjumlahan semua skor pertanyaan jika koefisien korelasi yang diperoleh lebih besar dari 0,3 maka pertanyaan tersebut valid. Berdasarkan hasil uji validitas dari ketiga variabel bahwa dari seluruh butir semuanya valid, karena nilai $r$ hitung (korelasi) lebih besar dari 0,3 .

Uji reliabilitas instrument bertujuan untuk mengetahui besarnya indeks instrument dari variabel. Setelah dilakukan uji validitas dan diperoleh butir pernyataan yang valid, selanjutnya dilakukan uji reliabilitas dengan menggunakan rumus Cronbach Alpha. Keputusan untuk mengetahui bahwa pertanyaan adalah reliabel jika nilai $\mathrm{r}$ Alpha $>0,6$. Dari hasil uji reliabilitas instrument menunjukkan bahwa ketiga variabel yaitu pemahaman wajib pajak, manfaat pajak restoran dan kesadaran mambayar pajak adalah reliabel karena nilai $\mathrm{r}$ Alpha > 0,6.

\section{Uji Asumsi Klasik}

Dari uji asumsi klasik yang dilakukan dengan menggunakan bantuan SPSS dapat disimpulkan model regresi memenuhi asumsi normalitas dan tidak adanya masalah heteroskedastisitas, dalam penelitian ini juga bebas dari problem autokorelasi atau kesalahan pengganggu sebab DW terletak diantara -2 sampai +2 yang berarti bebas dari autokorelasi. Tidak adanya multikolinieritas variabel bebas dalam persamaan regresi.

\section{Analisis Regresi Linear Berganda}

Persamaan regresi linear berganda dalam olahan data dengan menggunakan bantuan SPSS untuk menjelaskan pengaruh pemahaman wajib pajak restoran tentang pajak, dan manfaat yang di rasakan wajib pajak restoran terhadap kesadaran membayar pajak di Kota Tomohon adalah $\mathrm{Y}=8.000+0,136 \mathrm{X}_{1}+0,440 \mathrm{X}_{2}$

\section{Pembahasan \\ Pengaruh Pemahaman Wajib Pajak Terhadap Kesadaran Membayar Pajak Restoran $\left(\mathbf{X}_{1}\right)$}

Uji hipotesis dengan menggunakan uji t menunjukan bahwa pemahaman wajib pajak tidak berpengaruh signifikan terhadap kesadaran wajib pajak restoran di kota Tomohon, karena wajib pajak kurang memahami tentang perpajakan, sehingga pemerintah kota Tomohon perlu melakukan penyuluhan atau sosialisasi, serta pelatihan mengenai tata cara perpajakan sehingga mempengaruhi mereka dalam membayar pajak. Tingkat pemahaman wajib pajak ini dapat ditingkatkan dengan bimbingan oleh fiskus saat melaksanakan kewajiban perpajakannya. Pemahaman wajib pajak terhadap peraturan perundang-undangan perpajakan yang berlaku tidak berpengaruh terhadap kesadaran wajib pajak, dimana pemahaman wajib pajak terhadap peraturan perundangundangan perpajakan yang berlaku sangatlah penting untuk dapat melaksanakan dan memenuhi kewajibannya sesuai dengan ketentuan yang berlaku sehingga kesadaran wajib pajak dapat ditingkatkan (Gunadi, 2006).

\section{Pengaruh Manfaat Pajak Restoran Terhadap Kesadaran Membayar Pajak Restoran $\left(\mathbf{X}_{2}\right)$}

Uji hipotesis dengan menggunakan uji t menunjukan bahwa manfaat pajak restoran berpengaruh signifikan terhadap kesadaran wajib pajak di kota Tomohon, karena wajib pajak sudah merasakan secara tidak langsung bentuk-bentuk kontraprestasi dari pemerintah. Seperti melihat banyak dibangunnya fasilitas umum dan prasarana yang dibiyai dari APBN atau APBD. Merasakan keamanan dan stabilitas negara karena aparatur negara maupun prasarana dan sarana pertahan dan keamanan negara telah dibiayai dengan pajak. Manfaat yang dirasakan wajib pajak adalah guna atau faedah atau baik dan buruknya pajak yang dapat diterima atau dirasakan oleh wajib pajak. Wajib pajak tidak mendapatkan imbalan secara langsung dengan apa yang telah dibayarkannya pada pemerintah. Pemerintah tidak memberikan nilai atau penghargaan atau keuntungan kepada wajib pajak secara langsung. Apa yang telah dibayarkan oleh wajib pajak kepada pemerintah digunakan untuk keperluan umum pemerintah 


\section{Kesimpulan}

\section{PENUTUP}

Adapun kesimpulan yang disimpulkan oleh penulis dalam penelitian ini sebagai berikut :

1. Hasil penelitian menunjukan bahwa pemahaman wajib pajak berpengaruh terhadap kesadaran membayar pajak restoran di kota Tomohon.

2. Manfaat yang dirasakan wajib pajak berpengaruh terhadap kesadaran membayar pajak restoran di kota Tomohon.

3. Secara bersama - sama pemahaman wajib pajak dan manfaat yang dirasakan pajak berpengaruh signifikan terhadap kesadaran wajib pajak restoran di kota Tomohon.

\section{Saran}

1. Berdasarkan hasil penelitian terlihat bahwa manfaat yang dirasakan wajib pajak berpengaruh terhadap kesadaran membayar pajak restoran di kota Tomohon sehingga sangat perlu untuk meningkatkan himbauan dan pengawasan terhadap wajib pajak restoran yang baru terdaftar agar lebih sadar dan patuh akan kewajiban dan lebih transparan dalam melakukan kewajiban perpajakan.

2. Dalam rangka meningkatkan penerimaan pajak restoran, maka pemerintah khususnya pemerintah Kota Tomohon perlu memberikan motivasi kepada wajib pajak restoran untuk membayar pajak.

\section{DAFTAR PUSTAKA}

Adriani. 2010, Perpajakan Indonesia. Salemba Empat. Jakarta.

Brotodiharjo. 2011. Pengantar Ilmu Hukum Pajak, PT Rafika Aditama, Bandung

Boediono. 2010. Perpajakan Indonesia. Diadit Media. Jakarta.

Bohari. H. 2010. Pengantar Hukum Pajak. Penerbit PT. Raja Grafindo Persada. Jakarta.

Devano. Sony dan Siti Kurnia Rahayu. 2008, Perpajakan Konsep, Teori, dan Isu, Kenana. Jakarta.

Dinas Pendapatan Daerah (DISPENDA) Kota Tomohon. 2008. Peraturan Daerah Kota Tomohon No.16 Tahun 2005 Tentang Pajak Restoran. Tomohon.

Gunadi. 2006. Kebijakan Pemeriksaan Pajak Pasca Berlakunya Undang-Undang Perpajakan Baru. Berita Pajak. www.google.co.id.

Harahap. Abdul Asri. 2004. Paradigma Baru Perpajakan Indonesia. Integrita Dinamika Press: Jakarta.

Kuncoro Mudrajat. 2011. Metode Riset Untuk Bisnis dan Ekonomi. Penerbit Erlangga. Jakarta.

Mardiasmo. 2011. Perpajakan. Edisi Revisi. CV. Andi Offset. Yogyakarta.

Muljono. 2010. Panduan Brevet Pajak. CV. Andi Offset. Yogyakarta.

Prasetyo Fery Dwi. 2010. Analisis Faktor-Faktor yang Mempengaruhi Pemilik Usaha Kecil Menegah dalam Pelaporan Kewajiban Perpajakan di Daerah Jogjakarta (studi kasus pada usaha coffeshop di Daerah Jogjakarta). Jurnal Perpajakan Indonesia. Vol. 4 No. 4. November. 2010.

Republik Indonesia. Undang-undang Nomor 28 Tahun 2008 tentang Ketentuan Umum dan Tata Cara Perpajakan. Jakarta.

Rochmat Soemitro. 2010. Dasar-Dasar Hukum Pajak Pendapatan. Penerbit PT. Eresco. Bandung.

Siahaan Marihot. 2008 Pajak Daerah dan Retribusi Daerah. Cetakan Pertama. Jakarta. PT Raja Grafindo Persada.

Soemarso. 2008. Akuntansi Suatu Pengantar. Salemba Empat. Jakarta.

Sugiyono. 2010. Metode Penelitian Bisnis. Penerbit AlfaBeta. Bandung.

Sumarsan. Thomas. 2012. Perpajakan Indonesia. PT. Index. Jakarta

Trisnawati. 2009. Akuntansi Perpajakan. Salemba Empat. Jakarta.

William Melandri. 2006. Pengaruh Pemahaman Wajib Pajak, Persepsi Wajib Pajak Tentang Sanksi dan Pelayanan Pemerintah Terhadap Kepatuhan Wajib Pajak (Studi Empiris Terhadap Wajib Pajak Restoran di Kota Surabaya Cabang Selatan). Skripsi Pada FE UPN Jawa Timur. 